\title{
KLT-Bioautografi Ekstrak Etil Asetat Supernatan Hasil Fermentasi Streptomyces G Isolat Tanah Rumah Kompos Bratang Surabaya
}

Ifah Yulistyani ${ }^{1}$, Achmad Toto Poernomo $^{2}$, Isnaeni ${ }^{2 *}$

${ }^{1}$ Program Studi Magister Ilmu Farmasi, Fakultas Farmasi, Universitas Airlangga, Surabaya, Indonesia

${ }^{2}$ Departemen Ilmu Kefarmasian, Fakultas Farmasi, Universitas Airlangga, Surabaya, Indonesia

*Corresponding author: isnaeni@ff.unair.ac.id

Submitted: 16 Februari 2020

Accepted: 23 December 2020

Published: 27 April 2021

\begin{abstract}
Background: The rapid development of microorganisms behavior through various mechanisms reflected in various resistant strains, tolerant and persistent characters, such as Multi Drug Resistant (MDR), Extended Strain Beta Lactamase, MDR-Tuberculosis and Methicillin Resistant Staphylococcus Aureus. Efforts to explore new antibiotics from various natural sources have been done to overcome problems related to the need for antibiotics that are responsible for handling infectious diseases. Objectives: This research focuses on the isolation of Streptomyces sp. from compost waste land in the Bratang area of Surabaya that were able to produce anti-bacterial compounds. Methods: The Streptomyces sp. was successfully isolated and identified as Streptomyces G by which fermentation process was performed in the International Streptomyces Project-4 media. Thin Layer Chromatography-Bioautography method was used to evaluate the antibacterial activity of ethyl acetat extract of cell free fermentation broth (CFFB) against Escherichia coli ATCC 7890 and Staphylococcus aureus ATCC 23456. Results: The CFFB supernatant exhibited ability to inhibit the tested bacteria growth. The active compound was successfully extracted from the supernatant by ethyl acetate. The TLC-bioautogram using eluent of butanol : acetic acid: water (3:2: 6, v/v) showed that two spots were good separately, one of those $(R f=0.56)$ inhibited the tested bacteria with a weak potential category. Conclusion: Ethyl acetate extract of CFFB supernatant of Streptomyces G in ISP-4 media contained two different compounds and one of them showed growth inhibitory activity against Staphylococcus aureus ATCC 6538 and Escherichia coli ATCC 8739 based on the TLCbioautogram.
\end{abstract}

Keywords: Streptomyces sp-G, compost, waste-soil, TLC-bioautography

\begin{abstract}
Abstrak
Pendahuluan: Meningkatnya penggunaan antibiotika yang tidak rasional menyebabkan berkembangnya masalah resistensi obat anti infeksi. Perkembangan perilaku mikroorganisme yang luar biasa pesatnya melalui berbagai mekanisme telah melahirkan berbagai strain yang resisten, toleran dan persisten, antara lain, Multi Drug Resistant (MDR), Extended Strain Betalactamase, MDR-Tuberkulosis dan Methicillin Resistant Staphylococcus aureus. Upaya untuk mengeksplor antibiotika baru dari berbagai sumber alam telah banyak dilakukan untuk mengatasi permasalahn terkait kebutuhan antibiotika yang handal dalam mengatasi penyakit infeksi. Tujuan: Penelitian ini berfokus pada isolasi Streptomyces sp.yang mampu menghasilkan senyawa anti bakteri dari tanah kompos buangan sampah di daerah Bratang Surabaya. Metode: Streptomyces sp. telah berhasil diisolasi dan diidentifikasi sebagai Streptomyces G dan dilakukan proses dalam media ISP-4. Metode KLT-bioautografi digunakan untuk mengevaluasi aktivitas antibakteri ekstrak etil asetat supernatan kaldu fermentasi terhadap Escherichia coli ATCC 7890 dan Staphylococcus aureus ATCC 23456. Hasil: Supernatan menunjukkan kemampuan untuk menghambat pertumbuhan bakteri uji. Senyawa aktif berhasil diekstraksi dari supernatan dengan etil asetat dan KLTbioautogram menggunakan eluen butanol-asam asetat-air (3:2:6, v/v) menunjukkan bahwa ada dua noda yang terpisah secara baik, salah satu dari noda dengan Rf 0,56 mampu menghambat bakteri uji dengan kategori potensi lemah. Kesimpulan: Ekstrak etil asetat supernatan kaldu fermentasi Streptomyces G dalam media ISP-4
\end{abstract}


mengandung dua senyawa yang berbeda dan satu diantaranya menunjukkan aktivitas penghambatan terhadap pertumbuhan Staphylococcus aureus ATCC 6538 dan Escherichia coli ATCC 8739 berdasarkan data KLTbioautogram.

Kata kunci: Streptomyces $s p-G$, tanah kompos, aktivitas antibakteri

\section{PENDAHULUAN}

Actinomycetes termasuk bakteri berfilamen golongan Gram positif, saprofitik yang mampu hidup bebas di berbagai habitat, dan dikenal sebagai sumber berbagai antibiotik (Valli dkk., 2012; Al-Dhabi dkk., 2019) yang sebagian besar sudah digunakan di klinik. Actinomycetes ditemukan di laut, lingkungan muara, tanah dan air tawar (Gebreyohannes dkk., 2013), serta memiliki sifat antara bakteri dan jamur (Pandey dkk., 2004). Actinomycetes tercatat sebagai salah satu bakteri penghasil antibiotik selain fungi dan beberapa mikroba lainnya. Dari sekitar 11.900 jenis antibiotik yang ditemukan, kurang lebih $66 \%$ dihasilkan oleh actinomycetes dan hampir $80 \%$ dari jumlah tersebut ditemukan dalam Streptomyces spp., 22\% dihasilkan oleh jamur, $12 \%$ dihasilkan oleh bakteri selain actinomycetes.

Streptomyces sp. dikenal sebagai produsen antibiotik penting, menghasilkan tiga perempat dari semua antibiotik yang tersedia secara komersial. Pada penelitian sebelumnya telah diketahui bahwa Streptomyces sp. memproduksi bermacam-macam antibiotik antara lain streptomisin, kloramfenikol, tetrasiklin, eritromisin, bleomisin, kanamisin, dan masih banyak lagi antibiotik lainnya (Hopwood, 2007). Perbedaan geografis lokasi menyebabkan variasi jenis tanah dan antibiotik yang dihasilkan oleh Streptomyces (Nampoothiri dkk., 2002).

Dalam Actinomycetes, Streptomyces termasuk genus yang terpenting dan lebih dari 1000 species telah ditemukan (Al-Ansari dkk., 2019). Penelitian ini bertujuan mengisolasi dan melakukan penapisan daya antibakteri Streptomyces sp. dari tanah Rumah Kompos Bratang Surabaya (RKBS), salah satu tempat pengolahan sampah yang terletak di bagian selatan Kebun Bibit Bratang, Surabaya. Penelitian terkait isolasi actinomycetes khususnya Streptomyces telah banyak dilaporkan, antara Cuesta dkk. (2012) telah mengisolasi 49 actinomycetes dari kompos dan 12 di antaranya termasuk spesies Streptomyces. Identifikasi senyawa aktif dengan Kromatografi Lapis Tipis (KLT)bioautografi juga dilaporkan. Choma (2005) telah menyampaikan konsep teknik pemisahan, identifikasi dan uji aktivitas senyawa aktif hasil isolasi dari bahan alam (Isnaeni dkk., 2017).

Telah melaporkan aktivitas antibakteri supernatan hasil fermentasi Streptomyces $s p$ dan hasil ekstraksinya dengan butanol yang diisolasi dari tanah kebun sayur terhadap bakteri Gram positif, Gram negatif termasuk Mycobacterium tuberculosis (Isnaeni dkk., 2016).

\section{BAHAN DAN METODE Bahan}

Streptomyces $\mathrm{G}$ isolat tanah RKBS diperoleh dari Departemen Kimia Farmasi Fakultas Farmasi Universitas Airlangga. Escherichia coli ATCC 8739 dan Staphylococcus aureus ATCC 6538 diperoleh dari Unit Layanan Pengujian Fakultas Farmasi Universitas Airlangga. Media International Streptomyces project (ISP-4) cair dan padat (Lampiran 1), media Nutrient Broth (Difco) (Lampiran 2), agar AA, streptomisin sulfat (Meiji), eritromisin stearat (Aditamaraya Farmindo), tetrasiklin hidroklorida (Interbat), $\mathrm{NaCl}$ p.a (Merck), air suling, metanol p.a.(Merck), etil asetat teknis (Merck), n-butanol p.a. (Merck), asam asetat p.a. (Merck), toluen p.a. (Merck), etanol p.a. (Merck), kalium permanganat (Merck), asam sulfat p.a. (Merck), anisaldehid (Merck), dapar fosfat (Millipore).

\section{Alat}

Timbangan analitik (Sartorius), otoklaf (Pressure Stem Sterilizer 0,14 Mpa), pH meter (Schott), termometer, Laminar Air Flow cabinet (type pvc-750 APG seisa KHUSO LTD), inkubator (Memmert), cawan petri, jarum penanam (Öse), mikropipet (Socorex), jangka sorong (Tricle Brand), hot plate, Spectrophotometer UV-Vis (Lovibond Spectro PC 22), Thermoshaker (Gerhardt Laboshake), rotavapour, bejana kromatografi, vortex, lempeng kromatografi lapis tipis Silica Gel $F_{254}$ (Merck, Germany), pipa kapiler $2 \mu \mathrm{L}$.

\section{Metode}

\section{Penyiapan starter Streptomyces G}

Sebanyak satu Öse koloni Streptomyces G digesekkan dalam $8 \mathrm{~mL}$ kultur media ISP-4 agar miring, diinkubasi pada suhu $28^{\circ} \mathrm{C}$ selama 48 jam. Suspensi bakteri disiapkan dengan cara menanamkan satu Öse koloni Streptomyces G dalam media ISP-4 cair dan 
diinkubasi pada suhu $28^{\circ} \mathrm{C}$ selama 48 jam, dikocok 150 rpm pada Termoshaker. Jumlah bakteri dalam kaldu fermentasi Streptomyces G dihitung dengan Angka lempeng Total (ALT). Sebanyak $1 \mathrm{~mL}$ kaldu fermentasi dimasukkan tabung reaksi berisi $9 \mathrm{~mL}$ larutan steril $0,9 \% \mathrm{NaCl}$, suspensi divortex hingga homogen. Selanjutnya dilakukan pengenceran dari $10^{-1}$ sampai $10^{-15}$. Dari masing-masing enceran diambil $1 \mathrm{~mL}$ menggunakan mikropipet, dicampur dengan $10 \mathrm{~mL}$ media ISP-4 Agar yang telah dicairkan suhu $45-50^{\circ} \mathrm{C}$, divortex hingga homogen, kemudian dituang ke dalam cawan Petri dan diinkubasi pada suhu $28^{\circ} \mathrm{C}$ selama 48 jam, percobaan dilakukan duplo. Cawan Petri yang mengandung koloni 30 - 300 digunakan sebagai dasar perhitungan ALT. Kaldu fermentasi Streptomyces G juga diukur transmitansnya dengan menggunakan spektrofotometer UV-Vis. Transmitans yang diperoleh akan digunakan sebagai dasar pemanenan biomassa atau starter pada proses fermentasi selanjutnya (Isnaeni dkk., 2016).

\section{Fermentasi Streptomyces G}

Sebanyak $25 \mathrm{~mL}$ suspensi Streptomyces G dipindahkan dari starter ke $250 \mathrm{~mL}$ media ISP-4 cair, kemudian dikocok pada Thermoshake dengan kecepatan $150 \mathrm{rpm}$ pada suhu $28^{\circ} \mathrm{C}$ selama $48 \mathrm{jam}$. Fermentasi dilakukan selama 10 hari. Pengambilan sampel selama fermentasi dilakukan setiap 24 jam, miselium bakteri dipisahkan dari kaldu hasil fermentasi dengan cara sentrifugasi $5000 \mathrm{rpm}$ selama 10 menit (Awad dkk., 2009). Parameter yang diamati adalah aktivitas antibakteri, pH, dan berat sel kering (Yücel \& Yamaç, 2010). Untuk menentukan berat sel kering, miselium isolat Streptomyces G dikeringkan pada $105^{\circ} \mathrm{C}$ selama 18 - 24 jam sampai diperoleh berat konstan (Yücel \& Yamaç, 2010).

\section{Isolasi metabolit antibakteri}

Supernatan dari kaldu fermentasi yang diperoleh diekstraksi dengan etil asetat 1:1 (v/v), dikocok selama 1 jam untuk menyempurnakan ekstraksi. Fase etil asetat dipisahkan dari fase air dan diuapkan sampai kering menggunakan rotavapour pada suhu $37^{\circ} \mathrm{C}$ dan residu yang diperoleh ditimbang. Ekstrak yang diperoleh digunakan untuk menentukan aktivitas antibakteri, Konsentrasi Hambat Minimum (KHM) dan untuk identifikasi dengan KLT-bioautografi (Singh \& Pandey, 2009; Kharat dkk., 2009).

\section{Penentuan aktivitas antibakteri \\ Penyiapan bakteri uji}

Sebanyak satu Öse koloni Escherichia coli ATCC 8739 dan Staphylococcus aureus ATCC 6538 masing- masing dibiakkan dalam $8 \mathrm{~mL}$ kultur media Nutrient Agar miring, kemudian diinkubasi pada suhu $37^{\circ} \mathrm{C}$ selama 24 jam.

\section{Penyiapan inokulum bakteri uji}

Mikroba uji pada agar miring 24 jam ditambah dengan $10 \mathrm{~mL}$ larutan steril $0,9 \% \mathrm{NaCl}$, kemudian dikocok sampai koloni di permukaan Agar terlepas dan tersuspensi dalam larutan $0,9 \% \mathrm{NaCl}$. Inokulum tersebut selanjutnya diukur transmitannya pada panjang gelombang $580 \mathrm{~nm}$ dengan spektrofotometer. Transmitan suspensi diatur sampai 25\% (Isnaeni dkk., 2017).

\section{Penyiapan media uji}

Disiapkan Petri yang diisi dengan media Nutrient Agar $12 \mathrm{~mL}$ sebagai base layer. Selanjutnya diambil masing-masing $8 \mu \mathrm{L}$ inokulum Escherichia coli ATCC 8739 dan Staphylococcus aureus ATCC 6538 (T 25\%) dimasukkan ke dalam $8 \mathrm{~mL}$ media Nutrient Agar sebagai sheed layer (Warsito dkk., 2017). Agar dicetak dengan perforator untuk membuat sumur pencadang dengan diameter $0,7 \mathrm{~cm}$ dan kedalaman $1 \mathrm{~cm}$.

\section{Uji potensi antibakteri}

Aktivitas antibakteri ditentukan dengan metode difusi agar. Ekstrak kering etil asetat supernatan hasil fermentasi Streptomyces G dilarutkan dalam $1 \mathrm{~mL}$ dapar fosfat $0,2 \mathrm{M}$ (pH 7.0). Dipipet $100 \mu \mathrm{L}$ larutan ekstrak dimasukkan ke dalam sumur agar, setelah seluruh pencadang terisi larutan uji, selanjutnya petri diinkubasi pada $37^{\circ} \mathrm{C}$ selama 24 jam. Diameter zona hambat yang terbentuk di sekitar pencadang diukur diamati dan diukur menggunakan jangka sorong (Nampoothiri dkk., 2002).

\section{Optimasi fase gerak KLT}

Dibuat beberapa macam sistem eluen dengan berbagai perbandingan. Sebanyak $10 \mu \mathrm{L}$ larutan sampel dan antibiotik standar $200 \mathrm{ppm}$ ditotolkan pada pelat KLT silica gel $\mathrm{F}_{254}$, kemudian dieluasi dengan masingmasing eluen. Pelat KLT hasil eluasi dikeringkan dan noda yang terbentuk diamati di bawah lampu UV dengan atau tanpa penampak noda. Noda yang tampak diberi tanda dan nilai Rf dihitung (Warsito dkk., 2017).

\section{Penapisan daya antibakteri fase gerak}

Ditotolkan sebanyak $10 \mu \mathrm{L}$ fase gerak, antibiotik standar, dan etil asetat sebagai blanko pada pelat KLT. Selanjutnya pelat KLT diletakkan di atas permukaan media Nutrient Agar yang telah ditanami bakteri uji, kemudian disimpan di dalam lemari es selama dua jam. Cawan petri dikeluarkan dari lemari es. Selanjutnya pelat KLT diangkat dari permukaan agar, kemudian diinkubasi pada suhu $37^{\circ} \mathrm{C}$ selama 24 jam. Zona jernih 
yang terbentuk pada posisi noda diamati dan diukur diameternya dengan jangka sorong (Warsito dkk., 2017).

\section{Kromatografi lapis tipis}

Sebanyak $10 \mu \mathrm{L}$ ekstrak etil asetat hasil fermentasi Streptomyces G dan antibiotik standar 200 ppm ditotolkan pada pelat KLT silica gel $F_{254}$. Pelat KLT dibuat dua bagian, bagian pertama digunakan untuk bioautografi dan bagian lainnya untuk menentukan profil kromatogram KLT. Pelat dieluasi dengan fase gerak hasil optimasi. Pelat KLT yang telah dieluasi dikeringkan dan noda yang terbentuk diamati di bawah lampu UV $365 \mathrm{~nm}$ dengan atau tanpa penampak noda. Noda yang tampak diberi tanda dan nilai Rf dihitung.

\section{KLT-Bioautografi}

Bioautogram dibuat dengan cara meletakkan hasil KLT di atas permukaan media Nutrient Agar yang mengandung bakteri uji, kemudian disimpan di dalam lemari es $\left(4^{\circ} \mathrm{C}\right)$ selama dua jam supaya proses difusi antibiotik dalam noda kromatogram ke media Nutrient Agar sempurna. Cawan petri dikeluarkan dari lemari es, pelat KLT diangkat dari permukaan agar, kemudian diinkubasi pada suhu $37^{\circ} \mathrm{C}$ selama 24 jam. Zona jernih yang terbentuk pada posisi noda diamati dan diukur diameternya dengan jangka sorong.

\section{Uji stabilitas terhadap panas}

Larutan ekstrak diuji stabilitasnya terhadap panas dengan meletakkan pelat KLT yang telah berisi ekstrak etil asetat pada suhu $60^{\circ} \mathrm{C}$ selama 30 menit dan $100^{\circ} \mathrm{C}$ selama 5 menit. Selanjutnya pelat KLT digunakan untuk uji bioautografi. Zona jernih yang diperoleh dibandingkan dengan larutan tanpa perlakuan panas (Yucel \& Yamac, 2009).

\section{Penentuan KHM}

Ekstrak kering etil asetat dilarutkan dalam metanol $10 \%$ (persentase ini diperoleh dari hasil penelitian pendahuluan dan pada konsentrasi ini pelarut tidak memberikan daya hambat terhadap bakteri uji). Penetuan KHM ini dilakukan menggunakan 96 - well plate steril. Pada penentuan KHM dilakukan seri pengenceran yaitu dari konsentrasi 5000 ppm sampai $10 \mathrm{ppm}$. Larutan hasil pengenceran disaring dengan membran filter steril Millipore 0,45 $\mu \mathrm{m}$ (Yucel \& Yamac, 2009). Kemudian sebanyak $100 \mu \mathrm{L}$ masingmasing filtrat ke dalam well yang telah diisi $20 \mu \mathrm{L}$ suspensi bakteri uji. Selanjutnya plate diinkubasi pada suhu $37^{\circ} \mathrm{C}$ selama 24 jam.

Sebanyak $10 \mu \mathrm{L}$ resazurin ditambahkan ke dalam masing-masing well, kemudian diinkubasi dilanjutkan pada suhu $37^{\circ} \mathrm{C}$ selama 3 jam. Perubahan warna yang terjadi dinilai secara visual. Setiap perubahan warna dari ungu ke merah muda dicatat sebagai hasil positif (Yucel \& Yamac, 2009). Konsentrasi terendah yang menyebabkan terjadinya perubahan warna dicatat sebagai nilai KHM, yaitu konsentrasi minimum yang menghambat pertumbuhan mikroorganisme uji.

\section{HASIL DAN DISKUSI}

\section{Penetapan ALT starter Streptomyces G}

Seri pengenceran suspensi Streptomyces G dari $10^{-1}$ sampai $10^{-15}$ dilakukan untuk menentukan jumlah Streptomyces $\mathrm{G}$ yang digunakan selama proses fermentasi. Dari hasil perhitungan angka lempeng total diperoleh jumlah koloni dalam suspensi Streptomyces G yang digunakan adalah $50 \times 10^{15} \mathrm{cfu} / \mathrm{mL}$ dan menghasilkan transmitan 3,5\% pada $530 \mathrm{~nm}$. Tahap ini dilakukan untuk mendapatkan jumlah biomassa yang cukup untuk proses fermentasi dan untuk mendapatkan kondisi yang reprodusibel, fermentasi dilakukan pada fase pertumbuhan atau logaritmik.

\section{Fermentasi isolat Streptomyces $\mathbf{G}$}

Pertumbuhan dan aktivitas Streptomyces G diamati setiap 24 jam selama 10 hari. Puncak aktivitas tercapai pada hari ke-5 (Tabel 1, Gambar 1). Berdasarkan diameter zona yang diperoleh $(10-15 \mathrm{~cm})$, senyawa aktif dikategorikan lemah). Selanjutnya proses fermentasi dihentikan untuk produksi metabolit aktif. Aktivitas ini spesifik tergantung spesies Streptomyces. Hasil ini sesuai dengan hasil yang dilaporkan oleh Singh \& Pandey (2009) yang melakukan fermentasi Streptomyces sp. selama 3 - 5 hari pada $\mathrm{pH}$ 6,9 - 7,0. Pada penelitian ini $\mathrm{pH}$ fermentasi berkisar 6,0 - 8,2. Zothanpuia dkk. (2018) melakukan fermentasi Streptomyces spp. dari sedimen dalam media LB yang dimodifikasi untuk isolasi senyawa antimikroba dan penapisan aktivitas, dilakukan selama 7 - 15 hari. Kondisi fermentasi untuk memperoleh senyawa aktif penting dioptimasi baik media, $\mathrm{pH}$, suhu dan kecepatan agitasi. 
Tabel 1. Profil pertumbuhan dan aktivitas antibakteri supernatan hasil fermentasi Streptomyces sp. G dalam media ISP-

\begin{tabular}{|c|c|c|c|c|}
\hline \multirow[b]{3}{*}{ Hari ke- } & \multicolumn{3}{|c|}{4 cair } & \multirow[b]{3}{*}{$\begin{array}{l}\text { Berat sel kering } \\
\left(\mathrm{x} 10^{-3} \mathrm{~g} / 10 \mathrm{~mL}\right)\end{array}$} \\
\hline & \multicolumn{2}{|c|}{ Diameter zona hambat (mm) } & \multirow[b]{2}{*}{$\mathrm{pH}$} & \\
\hline & $\begin{array}{c}\text { S. aureus ATCC } \\
6538\end{array}$ & $\begin{array}{c}\text { E. coli } \\
\text { ATCC } 8739\end{array}$ & & \\
\hline 0 & 9,30 & 9,35 & 7,16 & 18,10 \\
\hline 1 & 11,75 & 12,24 & 5,99 & 8,00 \\
\hline 2 & 12,26 & 13,21 & 5,96 & 12,60 \\
\hline 3 & 11,70 & 13,14 & 6,04 & 8,60 \\
\hline 4 & 11,83 & 12,06 & 6,55 & 20,50 \\
\hline 5 & 14,39 & 13,73 & 7,25 & 33,80 \\
\hline 6 & 10,29 & 11,93 & 7,61 & 30,00 \\
\hline 7 & 11,21 & 13,15 & 7,95 & 23,70 \\
\hline 8 & 10,88 & 13,18 & 8,01 & 14,40 \\
\hline 9 & 9,73 & 10,21 & 8,16 & 20,00 \\
\hline 10 & 10,23 & 9,75 & 8,16 & 22,40 \\
\hline
\end{tabular}

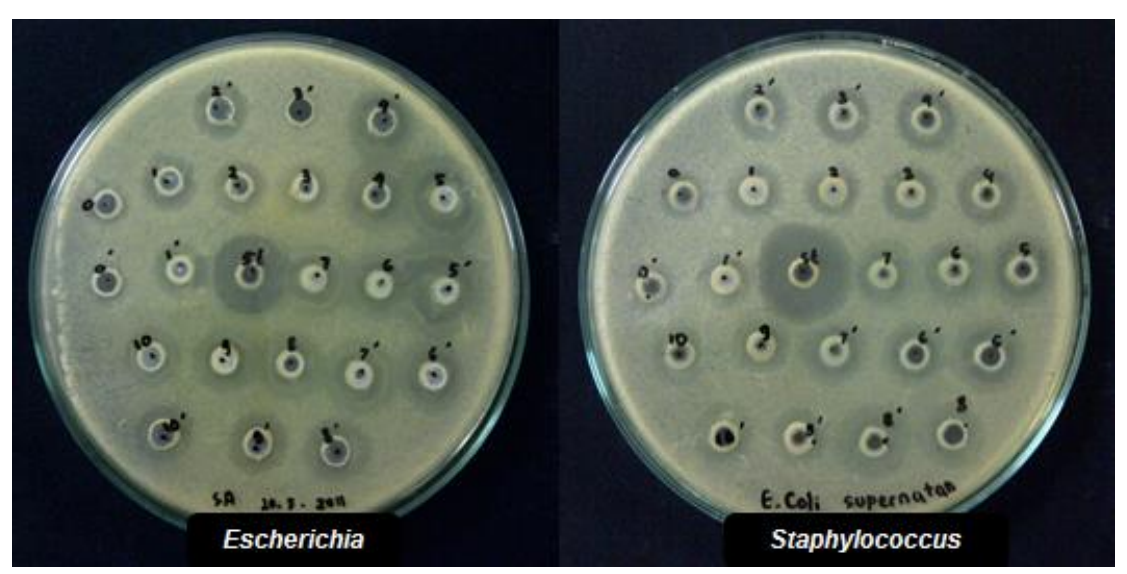

Gambar 1. Aktivitas antibakteri supernatan hasil fermentasi Streptomyces G terhadap Escherichia coli ATCC 8739 dan Staphylococcus aureus ATCC 6538 pada hari ke-1 sampai dengan ke-10 inkubasi

\section{Isolasi metabolit antimikroba}

Sebanyak 1 L kaldu fermentasi Streptomyces G diekstraksi dengan $1 \mathrm{~L}$ etil asetat (1:1) dan dikeringkan dengan rotavapor, sehingga didapatkan ekstrak kering seberat 830,4 mg. Etil asetat digunakan dengan tujuan mengisolasi seyawa aktif. Solvent yang digunakan untuk ekstraksi tergantung pada karakteristik senyawa aktif yang diisolasi. Singh \& Pandey (2009) menggunakan metanol:kloroform untuk melakukan gradient elusi menggunakan kromatografi kolom.

\section{Optimasi fase gerak KLT}

Hasil optimasi fase gerak diperoleh toluen : etanol $(8: 2)$ sebagai eluen terpilih, karena menghasilkan nilai Rf 0,2 - 0,8 (Tabel 2 dan Tabel 3) dan diperoleh dua noda yang terpisah. Harga Resolusi (Rs) kedua noda dapat dioptimasi untuk kesempurnaan pemisahan. Nilai Rs ini penting dipertimbangkan untuk analisis lanjut, terutama dengan KLT-bioautografi, karena ada faktor difusi senyawa aktif pada media uji.

Tabel 2. Hasil optimasi fase gerak KLT ekstrak etil asetat supernatan hasil fermentasi Streptomyces G

\begin{tabular}{clcc}
\multirow{2}{*}{ No. } & \multicolumn{1}{|}{ Sistem Fase Gerak } & \multicolumn{2}{c}{$\mathrm{R}_{f}$ noda } \\
\cline { 3 - 4 } & & Noda 1 & Noda 2 \\
\hline I & Metanol : air : etanol (75:20:5) & 0 & 0,93 \\
II & Toluen : etanol : asam asetat $(50: 40: 10)$ & 0,92 & - \\
III & n-butanol : asam asetat $(80: 20)$ & 0,87 & - \\
IV & Toluen : etanol $(8: 2)$ & 0,48 & 0,58 \\
\hline
\end{tabular}


Tabel 3. Hasil Pengamatan Rf pada kromatogram KLT menggunakan eluen toluen:etanol (8:2)

\begin{tabular}{lcc}
\hline \multirow{2}{*}{ Nama Sampel } & \multicolumn{2}{c}{ Nilai $\mathrm{R}_{f}$} \\
\cline { 2 - 3 } & Noda 1 & Noda 2 \\
\hline Streptomisin $*$ & - & - \\
Eritromisin & 0,15 & - \\
Tetrasiklin & 0 & - \\
Ekstak etil asetat & 0,56 & 0,67 \\
Streptomyces G & &
\end{tabular}

*) noda tidak nampak sehingga $\mathrm{R}_{f}$ tidak dapat dihitung

\section{Kromatografi lapis tipis}

Uji aktivitas antibakteri fase gerak terpilih dilakukan untuk mengetahui pengaruh fase gerak terhadap pertumbuhan bakteri uji. Hasil pengamatan (Gambar 2) menunjukkan bahwa fase gerak yang terpilih memiliki aktivitas antibakteri terhadap bakteri uji. Selanjutnya, perlu dilakukan pemanasan untuk menghilangkan sisa fase gerak dari pelat KLT sebelum dilakukan uji bioautografi. Hasil uji stabilitas terhadap panas menunjukkan bahwa noda stabil terhadap perlakuan panas.

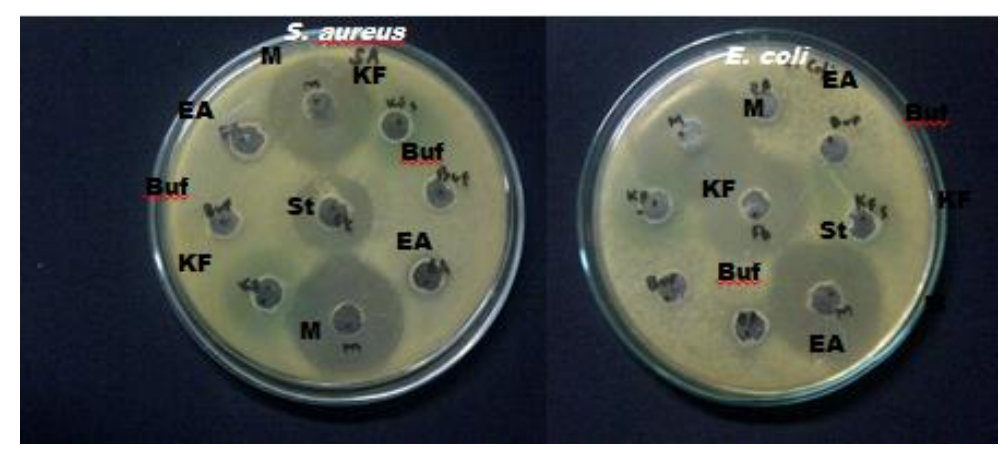

Gambar 2. Penapisan daya hambat ekstrak etil asetat supernatan hasil fermentasi Streptomyces G dalam dapar fosfat $0,2 \mathrm{M} \mathrm{pH}$ 7,0 terhadap Escherichia coli ATCC 8739 dan Staphylococcus aureus ATCC 6538; M = ekstrak etil asetat Streptomyces $\mathrm{G}$ dalam buffer fosfat $0,2 \mathrm{M} \mathrm{pH}$ 7,0; EA = etil asetat; $\mathrm{Buf}=$ dapar fosfat $0,2 \mathrm{M} ; \mathrm{KF}=$ kaldu fermentasi (sebelum diekstraksi); $\mathrm{St}=$ antibiotik standar (streptomisin $200 \mathrm{ppm}$ )

Berdasarkan data kromatogram dapat dinyatakan bahwa senyawa dalam ekstrak etil asetat hasil fermentasi Streptomyces G tidak sama dengan antibiotik standar yang digunakan (Gambar 3). Selanjutnya noda yang dihasilkan ekstrak etil asetat yang diamati di bawah lampu UV pada panjang gelombang yang berbeda menunjukkan bahwa pada $\lambda_{254}$ hanya terdeteksi satu noda, sedangkan pada $\lambda_{365}$ teramati dua noda (Gambar 4).

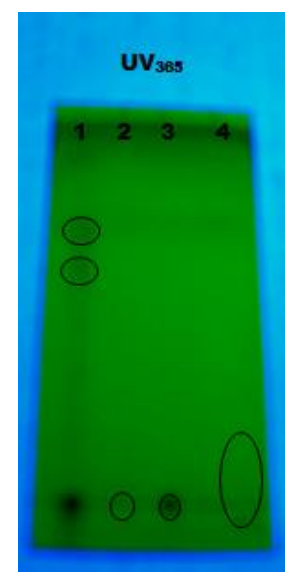

Gambar 3. Kromatogram KLT di bawah sinar $\mathrm{UV}_{365}$ dan dengan penampak noda larutan anisaldehid $1=$ ekstrak etil asetat hasil fermentasi Streptomyces G; $2=$ streptomisin; $3=$ tetrasiklin; $4=$ eritromisin 


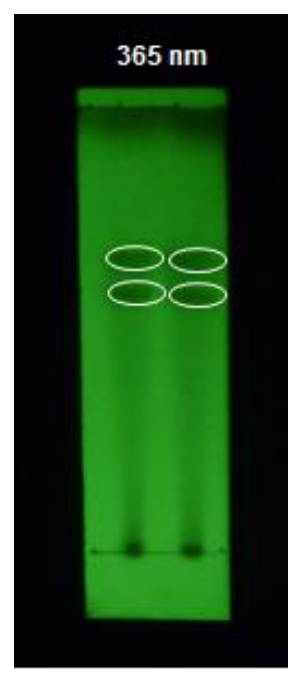

Gambar 4. Kromatogram KLT ekstrak etil asetat supernatan hasil fermentasi Streptomyces G menggunakan fase gerak toluen:etanol (8:2) di bawah sinar UV $365 \mathrm{~nm}$

\section{KLT-bioautografi}

Pada uji bioautografi noda yang memiliki aktivitas antibakteri terhadap bakteri uji hanya noda dengan $\mathrm{R}_{f}$ 0,56. Aktivitas antibakteri ditunjukkan dengan terbentuknya zona jernih pada bioautogram (Gambar 5). Bioautogram ekstrak etil asetat setelah perlakuan panas menunjukkan daya hambat, yang menunjukkan stabilitas senyawa aktif dalam ekstrak (Gambar 6). Teknik analisis yang banyak dibahas oleh Choma (2005) ini sangat menguntungkan, terutama untuk memisahkan campuran antibiotika, karena minimal diperoleh tiga informasi dari teknik ini, (1) jumlah senayawa, (2) aktivitas senyawa secara kualitatif, dan (3) potensi aktivitasnya. KLT-densitometri dapat digunakan untuk mendeteksi campuran analit dalam kromatogram, tetapi tidak mampu memberikan informasi aktivitasnya. Sebagai contoh gentamisin yang terdiri dari tiga komponen yang dapat dipisahkan dengan KLT dan diamati dengan densitometer (Isnaeni dkk., 2016), namun tidak dapat diketahui perbandingan aktivitas antibakteri ketiga komponen tersebut. Validasi metode KLT-bioautografi untuk penentuan kadar streptomisin sulfat telah dilakukan Warsito dkk. (2017) dan memberikan hasil yang memenuhi parameter validasi. Bakteri uji perlu diperbanyak untuk representasi aktivitas antimikroba senyawa yang terdeteksi pada kromatogram. Senyawa yang tidak aktif dengan mikroba uji yang digunakan pada penelitian ini dapat diujikan dengan galur atau spesies mikroba uji lain baik bakteri maupun jamur patogen.
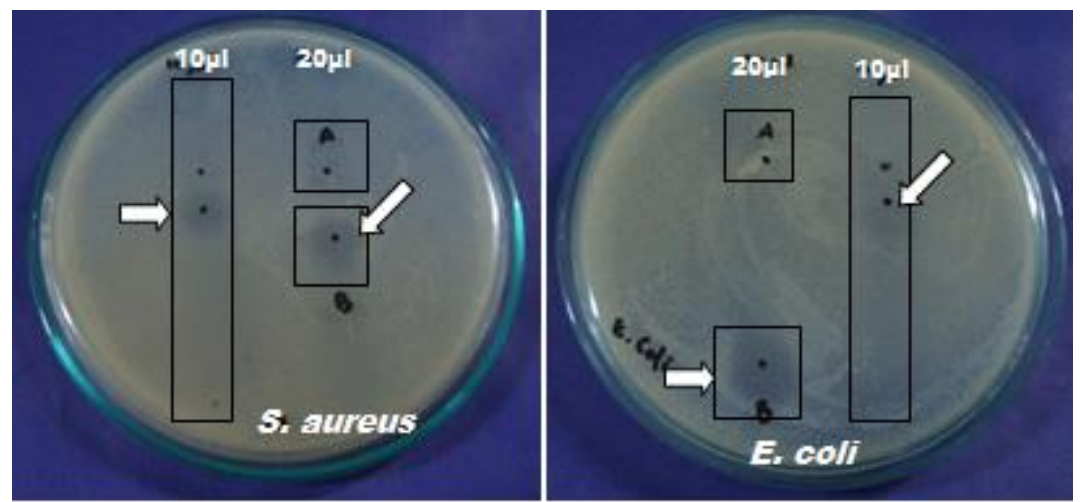

Gambar 5. Profil KLT-bioautogram ekstrak etil asetat Streptomyces G terhadap Escherichia coli ATCC 8739 dan Staphylococcus aureus ATCC 6538 (tanda panah menunjukkan noda yang aktif menghambat bakteri uji) 


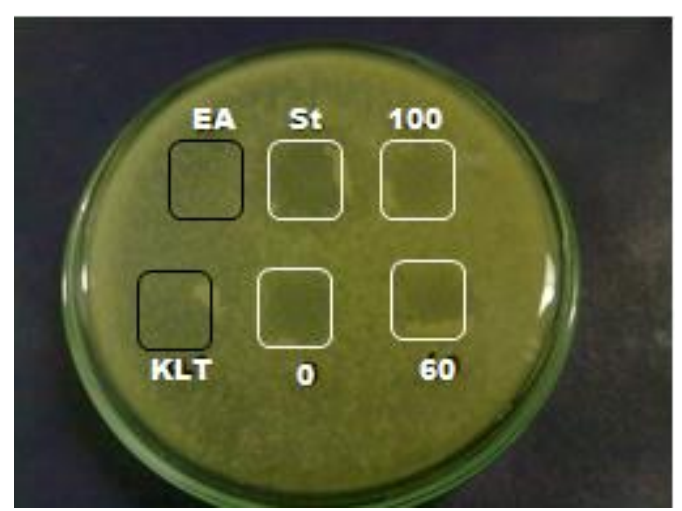

Gambar 6. Profil KLT-bioautogram ekstrak etil asetat supernatan hasil fermentasi Streptomyces G setelah perlakuan panas. $\mathrm{EA}=$ etil asetat; $\mathrm{KLT}=$ pelat $\mathrm{KLT}, \mathrm{St}=$ standar tetrasiklin; $0=$ Sampel tanpa perlakuan panas; $60=$ Sampel setelah dipanaskan $60^{\circ} \mathrm{C}$ selama 30 menit; $100=$ Sampel setelah dipanaskan $100^{\circ} \mathrm{C}$ selama 5 menit

\section{Penentuan konsentrasi hambat minimum (KHM)}

Pada penentuan KHM menggunakan uji modifikasi resazurin, aktivitas antibakteri ditandai dengan terbentuknya perubahan warna dari ungu menjadi merah muda (Gambar 7). Warna ungu atau biru menggambarkan adanya aktivitas antibakteri, sehingga bakteri uji tidak dapat tumbuh. Warna merah muda mengindikasikan adanya pertumbuhan bakteri uji. Berdasarkan data yang diperoleh ekstrak etil asetat hasil fermentasi Streptomyces G memiliki nilai KHM 128,75 ppm dan 2575 ppm masing-masing terhadap Escherichia coli ATCC 8739 dan Staphylococcus aureus ATCC 6538 (Gambar 7).

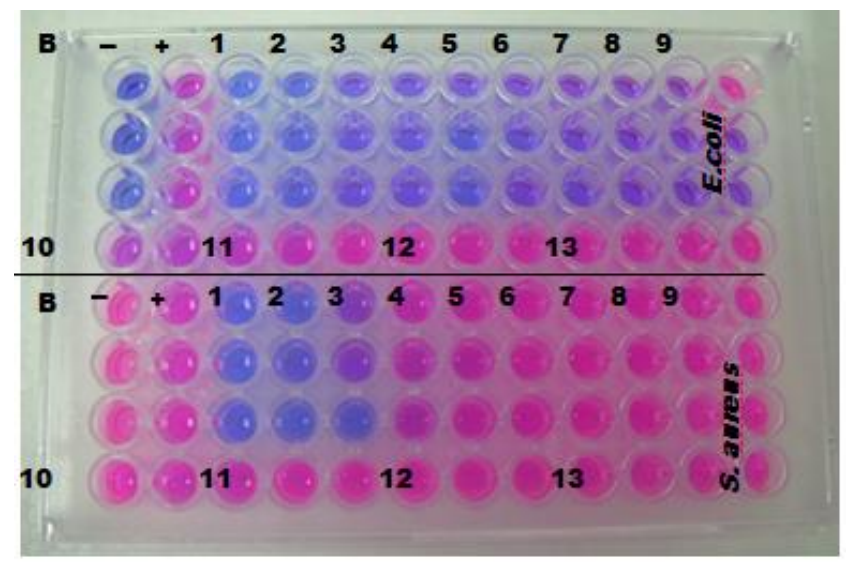

Gambar 7. Konsentrasi hambat minimum ekstrak metanol 10\% supernatan hasil fermentasi Streptomyces G terhadap Escherichia coli ATCC 8739 dan Staphylococcus aureus ATCC 6538 menggunakan resazurin sebagai indikator. B = blanko (media Nutrient Broth); - = kontrol negatif (metanol 10\%); + = streptomisin 202 ppm (kontrol positif); $1=$ ekstrak dalam metanol 10\% (5150 ppm); $2=$ ekstrak dalam metanol 10\% (2575 ppm); $3=$ ekstrak dalam metanol 10\% (1030 ppm); 4 = ekstrak dalam metanol 10\% (772,5 ppm); 5 = ekstrak dalam metanol $10 \%$ (515 ppm); 6 $=$ ekstrak dalam metanol 10\% (257,5 ppm); 7 = ekstrak dalam metanol 10\% (206 ppm); $8=$ ekstrak dalam metanol 10\% $(128,75 \mathrm{ppm}) ; 9=$ ekstrak dalam metanol 10\% (103 ppm); $10=$ ekstrak dalam metanol 10\% (77,25 ppm); $11=$ ekstrak dalam metanol 10\% (51,5 ppm); $12=$ ekstrak dalam metanol 10\% (25,75 ppm); $13=$ ekstrak dalam metanol $10 \%$ $(10,3 \mathrm{ppm})$

\section{KESIMPULAN}

Ekstrak Streptomyces G mengandung 2 senyawa yang berbeda dan hanya ada satu senyawa $\left(\mathrm{R}_{f} 0,53\right)$ yang memiliki aktivitas antibakteri terhadap Staphylococcus aureus ATCC 6538 serta Escherichia coli ATCC 8739.

\section{UCAPAN TERIMA KASIH}

Terima kasih kepada Research Group Isolasi senyawa aktif dari Streptomyces sp., outbound Students program yang telah memfasilitasi penelitian ini bekerjasama dengan UITM. 


\section{DAFTAR PUSTAKA}

Al-Ansari, M., Alkubaisi, N., Vijayaragavan, P. \& Murugan, K. (2019). Antimicrobial Potential of Streptomyces Sp. to the Gram Positive and Gram Negative Pathogens. Journal of Infection and Public Health; 12; 861-866.

Al-Dhabi, N. A., Ghilan, A. M., Esmail, G. A., Arasu, A. V., Duraipandiyan, V. \& Ponmurugan, K. (2019). Bioactivity Assessment of the Saudi Arabian Marine Streptomyces Sp. Al-Dhabi-90, Metabolic Profiling and Its in Vitro Inhibitory Property against Multidrug Resistant and Extended-Spectrum Beta-Lactamase Clinical Bacterial Pathogens. Journal of Infection and Public Health; 12; 549-56.

Awad, H. M., El-Sahed, K. \& El-Nakkadi, A. (2009). Isolation, Screening and Identification of Newly Isolated Soil Streptomyces (Streptomyces Sp. NRC-35) for b-Lactamase Inhibitor Production. World Applied Sciences Journal; J7; 637-646.

Choma, I. (2005). The Use of Thinl-Layer Chromatography with Direct Bioautography for Antimicrobial Analysis. Chromatography Online; 18; 482-488.

Cuesta, G., García-de-la-Fuente, G., Abad, M. \& Fornes, F. (2012). Isolation and Identification of Actinomycetes from a Compost-Amended Soil with Potential as Biocontrol Agents. Journal of Environmental Management; 95; S280-S284.

Gebreyohannes, G., Moges, F., Sahile, S. \& Raja, N. (2013). Isolation and Characterization of Potential Antibiotic Producing Actinomycetes from Water and Sediments of Lake Tana, Ethiopia. Asian Pacific Journal of Tropical Biomedicine; 3; 426-435.

Hopwood, D. A. (2007). Streptomyces in Nature and Medicine: The Antibiotic Makers. Oxford; University Press.

Isnaeni, Astuti, A. \& Yuwono, M. (2017). Validation of Thin-Layer Chromatography-Bioautographic Method for Determination of Streptomycin. Jurnal Farmasi dan Ilmu Kefarmasian Indonesia; 4; 34-38.
Isnaeni, Kusumawati, I., Warsito, M. F., Darmawati, A. \& Mertaniasih, N. M. (2016). Antimicrobial Activity of Streptomyces Sp. Isolates from Vegetable Plantation Soil. Berkala Penelitian Hayati; 21; 69-74.

Kharat K. R., Kharat A. \& Hardikar, B. P. (2009). Antimicrobial and Cytotoxic Activity of Streptomyces sp. from Lonar Lake. African Journal of Biotechnology; 8; 6645-6648.

Nampoothiri, K. M., Ramachandran, S., Soccol, C. R. Pandey, A. (2002). Advances in Fermentation Technology. International Sugar Journal; 104; 493-499.

Pandey, B., Prakash, G. \& Vishwanath, P. A. (2004). Studies on the Antibacterial Activity of the Actinomycetes Isolated from the Khumbu Region of Nepal. Journal of Applied Microbiology ; 12; 421-423.

Singh, P. N. N. \& Pandey, A. (2009). Biotechnology for Agro-Industrial Residues Utilisation. Dordrecht: Springer.

Valli, S., Suvathi, S. S, Aysha, O. S., Nirmala, P., Kumar, P. V. \& Reena, A. (2012). Antimicrobial Potential of Actinomycetes Species Isolated from Marine Environment. Asian Pacific Journal of Tropical Biomedicine; 2; 469-473.

Warsito, M. F., Nasution, N. E., Merthaniasih, N. M., Poernomo, A. T., Fairuz, D. \& Hanifah, A. (2017). Antibacterial Activity of Butanol Extract from Cell Free Fermentation Broth of Streptomyces Sp. Isolated from Vegetable Plantation Soil. Research Journal of Pharmaceutical, Biological and Chemical Sciences; 8; 1921-1927.

Yücel, S. \& Yamaç, M. 2010. Selection of Streptomyces Isolates from Turkish Karstic Caves against Antibiotic Resistant Microorganisms. Pakistan Journal of Pharmaceutical Sciences; 23; 1-6.

Zothanpuia, A., Passari, K., Preeti, C., Vineet, K., Mishra, B. K. \& Bhim, P. S. (2018). Production of Potent Antimicrobial Compounds from Streptomyces cyaneofuscatus Associated with Fresh Water Sediment. Frontier Microbiology; 10; 1681. 